\title{
The chemosensitizing activity of inhibitors of glucosylceramide synthase is mediated primarily through modulation of P-gp function
}

\author{
LILLY CHAI*, RAJASHREE P. MCLAREN*, ANN BYRNE*, WEI-LIEN CHUANG, YINYIN HUANG, \\ MICHAEL R. DUFAULT, JOSHUA PACHECO, SHRUTI MADHIWALLA, XIAOKUI ZHANG, \\ MINDY ZHANG, BEVERLY A. TEICHER, KARA CARTER, SENG H. CHENG, JOHN P. LEONARD, \\ YIBIN XIANG, MICHAEL VASCONCELLES, MARK A. GOLDBERG, DIANE P. COPELAND, \\ KATHERINE W. KLINGER, JAMES LILLIE, STEPHEN L. MADDEN and YIDE A. JIANG
}

Genzyme Corporation, 49 New York Avenue, Framingham, MA 01701, USA

Received August 18,2010; Accepted October 8, 2010

DOI: $10.3892 /$ ijo.2010.888

\begin{abstract}
Glucosylceramide synthase (GCS) is a key enzyme engaged in the biosynthesis of glycosphingolipids and in regulating ceramide metabolism. Studies exploring alterations in GCS activity suggest that the glycolase may have a role in chemosensitizing tumor cells to various cancer drugs. The chemosensitizing effect of inhibitors of GCS (e.g. PDMP and selected analogues) has been observed with a variety of tumor cells leading to the proposal that the sensitizing activity of GCS inhibitors is primarily through increases in intracellular ceramide leading to induction of apoptosis. The current study examined the chemosensitizing activity of the novel GCS inhibitor, Genz-123346 in cell culture. Exposure of cells to Genz-123346 and to other GCS inhibitors at nontoxic concentrations can enhance the killing of tumor cells by cytotoxic anti-cancer agents. This activity was unrelated to lowering intracellular glycosphingolipid levels. Genz-123346 and a few other GCS inhibitors are substrates for multi-drug reisistance efflux pumps such as P-gp (ABCB1, gP-170). In cell lines selected to over-express P-gp or which endogenously express P-gp, chemosensitization by Genz-123346
\end{abstract}

Correspondence to: Dr Yide Jiang or Dr Stephen L. Madden, Genzyme Corporation, 49 New York Avenue, Framingham, MA 01701, USA

E-mail: yide.jiang@genzyme.com steve.madden@genzyme.com

${ }^{*}$ Contributed equally

Abbreviations: MDR, multidrug resistance; GSLs, glycosphingolipids; GCS, glucosylceramide synthase; GM3S, GM3 synthase; PDMP, DL-threo-1-phenyl-2-decanoylamino-3-morpholino-1propanol; CER, ceramide; GL1, glucosylceramide; GL2, lactosylceramide; GL3, triglycosylceramide

Key words: glucosylceramide synthase, GCS inhibitor, chemosensitization, P-glycoprotein was primarily due to the effects on P-gp function. RNA interference studies using siRNA or shRNA confirmed that lowering GCS expression in tumor cells did not affect their responsiveness to commonly used cytotoxic drugs.

\section{Introduction}

Treatment failure with certain anti-cancer agents can be associated with the expression of multidrug resistance (MDR) efflux pumps by malignant cells including the ATP-dependent drug efflux proteins that belong to the super family of ATPbinding cassette $(\mathrm{ABC})$ transporter proteins, such as $\mathrm{ABCB} 1$ (P-gp) or MDR1 $(1,2)$. Moreover, there is emerging evidence that lipids, particularly sphingolipids, glycosphingolipids and cholesterol, may also play a role in drug resistance, possibly in concert with $\mathrm{ABC}$ transporter proteins $(3,4)$. Much of the evidence for a relationship between MDR and sphingolipids comes from studies using anti-cancer drug selected cancer cell lines which have multiple alterations in sphingolipid levels compared with the parental drug-sensitive cells. Glucosylceramide (GL1), a precursor of all complex glycosphingolipids and a direct metabolic product of ceramide (CER), is consistently elevated in several P-gp-over-expressing cell lines (5). It has been proposed that the accumulation of GL1 is a characteristic biomarker of some multidrug-resistant cancer cells and tumors derived from patients whose tumors are weakly responsive to chemotherapy (6).

The enzyme responsible for the synthesis of GL1 is glucosylceramide synthase (GCS or UDP-glucose ceramide glucosyltransferase, UGCG). GCS catalyzes the first step in the biosynthesis of glycosphingolipids, and its cellular activity modulates the levels of the other lipids as well as ceramide (7-9). Early studies demonstrated that increasing the capacity for ceramide glycosylation in GCS-transfected human breast cancer MCF-7 cells conferred greater resistance to doxorubicin and to TNF- $\alpha(10,11)$. In contrast, exposing multi-drug-resistant tumor cell lines to antisense oligonucleotides directed toward GCS mRNA increased sensitivity to doxorubicin $(12,13)$. Furthermore, basic cellular functions, such as growth and morphology, are affected in cells treated 
with different GCS inhibitors (14-16). Moreover, these compounds have been reported to sensitize tumor cells to the cytotoxic effects of various anti-cancer compounds $(15,17)$. However, DL-threo-1-phenyl-2-decanoylamino-3-morpholino1-propanol (PDMP), a widely used GCS inhibitor in numerous studies, reportedly exhibits many non-specific actions, such as inhibition of other enzymes involved in glycolipid metabolism $(18,19)$, as well as affects on calcium homeostasis, membrane fluidity (20) and thymidine transport (21). The chemosensitizing effects of PDMP and/or its analogues in different types of tumor cells have been observed in various studies $(9,15,22-24)$. In general, the assumption has been that the sensitizing effect was due to inhibition of GCS, thereby resulting in increased ceramide levels and induction of apoptosis. However, recent studies suggest that the chemosensitizing effect of PDMP and its analogues may not be related to GCS inhibition (25-27). Iminosugar-based GCS inhibitors which are from a different chemical class than the ceramide-based inhibitor PDMP were observed to be ineffective in chemosensitizing multidrug-resistant tumor cells (25). Moreover, the chemosensitizing effects of PDMP on neuroblastoma cells were GCS- and ceramide-independent (27). Therefore, questions exist regarding the role and mechanism of action associated with inhibition of GCS in chemosensitizing tumor cells.

Genz-123346 is a novel analogue of PDMP with improved specificity for inhibiting glucosylceramide synthase $(19,28,29)$. In this study, we examined the chemosensitizing effect of Genz-123346 on tumor cells and provide evidence suggesting that modulation of P-gp function may be the primary mode of action. Supporting this notion are studies using siRNA and shRNA showing that lowering of GCS levels did not alter tumor cell response to commonly used cytotoxic drugs which are efflux pump substrates.

\section{Materials and methods}

Reagents and cell culture. PBS, fetal bovine serum (FBS), RPMI medium, trypsin-EDTA, penicillin G sodium/streptomycin were purchased from Invitrogen, Inc. (Carlsbad, CA). PDMP (DL-threo-1-phenyl-2-decanoylamino-3-morpholino1-propanol), vinblastine, vincristine, docetaxel, doxorubicin, 5-fluorouracil (5-FU) and verapamil were purchased from Sigma Chemical Co. (St. Louis, MO). The C9DGJ (N-nonyldeoxygalactonojirimycin) and C4DGJ (N butyl-deoxygalactonojirimycin) were from Toronto Research Chemicals (Toronto, Canada). Genz-123346 was from Genzyme Corp. (Waltham, MA). Anti P-gp antibody was obtained from Cell Signaling Technology (Danvers, MA). Human colon carcinoma cell lines HCT-15 and human hepatocellular carcinoma cell line HepG2 were obtained from American Type Culture Collection (Manassas, VA). Human cervical carcinoma cell line KB3-1 and a vinblastine-selected subline KBV-1 were a gift from Dr E. J. LaVoie (Rutgers, New Jersey). All tumor cell lines are maintained in RPMI supplemented with $5 \%$ fetal bovine serum (FBS), penicillin $\mathrm{G}$ sodium $(100 \mathrm{U} / \mathrm{ml})$, and streptomycin $(100 \mu \mathrm{g} / \mathrm{ml})$. Vinblastine $(1 \mu \mathrm{g} / \mathrm{ml})$ was added only to the KBV-1 culture medium periodically to maintain drug-resistant phenotype (30). Cell lines were maintained in a humidified atmosphere at $37^{\circ} \mathrm{C} / 5 \% \mathrm{CO}_{2}$ for growth.
mRNA extraction and quantitative real-time PCR ( $q R T-P C R)$ analysis. Total RNA was extracted using the RNeasy mini kit (Qiagen GmbH, Valencia, CA) and first-strand cDNA was synthesized using random hexamer primers and Superscript II reverse transcriptase (Invitrogen). Purified total RNA was subjected to formaldehyde gel electrophoresis and spectrophotometry (A260 nm and A280 nm) to assess integrity and purity. qRT-PCR analysis was performed using an ABI-PRISM 7700 Sequence Detector System and the SYBR-Green PCR Master Mix kit (Applied Biosystems, Foster City, CA) according to the manufacturer's instructions. Primer and probe mixtures for genes of interest were pre-validated from ABI's 'assay on demand' (Applied Biosystems). The ribosomal protein RPLP0 (NM_001002) was used as internal standard.

RNA interference and generation of stable GCS RNAi HepG2 cells. siRNA (pool) for GCS was purchased from Dharmacon (Lafayette, CO) and resuspended to a concentration of $20 \mu \mathrm{M}$ in buffer. The scrambled non-targeting siRNA (NT siRNA siRNAs) was purchased from Qiagen (Valencia, CA).

HepG2 cells were cultured in RPMI media supplemented with 5\% FBS. RNAintro ${ }^{\mathrm{TM}}$ pSM2 retroviral vector (Open Biosystems, Huntsville, AL) was used to sub-clone nonsilencing or GCS shRNAs. The GCS shRNA sequence was designed using the online software from Open Biosystems. This vector contains a puromycin-resistant marker site for positive colony selection. The specificity of GCS shRNA was verified by transient transfection using Arrest-In transfect reagent (Open Biosystem) followed by Western blotting. To generate stable cell lines, shRNAs targeted to GCS or nonsilencing controls were transfected into HepG2 cells. Stable transfectants were selected in the presence of $2 \mu \mathrm{g} / \mathrm{ml}$ puromycin (Invitrogen), a working concentration determined previously by kill curves. Cells derived from these transfectants were used for qRT-PCR to confirm the decrease of GCS mRNA expression. GCS knockdown stable HepG2 cells were maintained in RPMI media supplemented with $5 \%$ FBS containing $1 \mu \mathrm{g} / \mathrm{ml}$ puromycin.

Cell viability/proliferation assay. Cells were resuspended in growth media at a concentration of 20,000 cells $/ \mathrm{ml}$. One hundred $\mu \mathrm{l}$ cell suspension $(2,000$ cells $)$ was seeded into each well of a 96-well flat bottom, tissue culture treated Corning PN 3595 plate (Corning, Corning, NY). The CellTiter-Glo ${ }^{\circledR}$ Luminescent Cell Viability Assay (Promega, Madison, WI) was used to measure viable cells. The protocol was followed according to the manufacturer's instructions. ATP content of the wells was measured using a BioTek Synergy ${ }^{\mathrm{TM}}$ 2-plate reader (Winooski, VT). Cells were treated for $72 \mathrm{~h}$ in assays and the effect of treatment on cell proliferation was calculated based on the National Cancer Institute drug screen assay (31).

Cell-free P-gp ATPase activity assay. Changes in Pg-p ATPase activity were detected by the Pg-p-Glo ${ }^{\text {TM }}$ assay system (Promega). According to the manufacturer's instructions, the activity of P-gp ATPase was measured in the presence or absence of $250 \mu \mathrm{M}$ sodium orthovanadate $\left(\mathrm{Na}_{3} \mathrm{VO}_{4}\right), 400 \mu \mathrm{M}$ verapamil (as a positive control) and various concentrations of PDMP, Genz-123346, C4DGJ diluted with assay buffer. Control or test compounds were incubated in $25 \mathrm{mM} \mathrm{MgATP}$ 
Table I. The GSL levels in human cervical carcinoma KB3-1 and drug-resistant subline KBV-1 cells.

\begin{tabular}{|c|c|c|c|c|c|c|}
\hline Cells & Cer & GL1 & GL3 & GL2 & GM3 & GM1 \\
\hline KB3-1 & $182.0 \pm 11.8^{\mathrm{a}}$ & $40.5 \pm 1.4$ & $321.0 \pm 0.6$ & $126.1 \pm 3.5$ & $57.8 \pm 1.6$ & $27.8 \pm 1.9$ \\
\hline \multicolumn{7}{|l|}{ KB3-1 } \\
\hline+ Genz-123346 & $160.7 \pm 17.2$ & $15.8 \pm 1.6$ & $23.3 \pm 17.0$ & $59.1 \pm 7.9$ & $10.2 \pm 2.4$ & $10.5 \pm 2.0$ \\
\hline $\mathrm{KBV}-1$ & $201.8 \pm 10.8$ & $64.4 \pm 5.4$ & $265.1 \pm 11.7$ & $247.8 \pm 12.8$ & $190.5 \pm 9.7$ & $154.4 \pm 44.4$ \\
\hline \multicolumn{7}{|l|}{ KBV-1 } \\
\hline +Genz-123346 ${ }^{\mathrm{b}}$ & $190.0 \pm 12.4$ & $31.3 \pm 5.8$ & $36.2 \pm 11.0$ & $99.5 \pm 33.4$ & $19.6 \pm 0.4$ & $30.6 \pm 13.4$ \\
\hline
\end{tabular}

and $25 \mu \mathrm{g}$ recombinant human $\mathrm{P}$-gp membranes at $37^{\circ} \mathrm{C}$ for $40 \mathrm{~min}$. The plate was moved to room temperature and the reactions were stopped by adding $50 \mu 1$ of ATP detection reagent. The plate was incubated at room temperature for 20 min to allow the luminescent signal to develop. Samples were transferred to a white opaque 96-well plate (Corning) for detection of luminescence. The level of luminescence was measured using a BioTek Synergy 2-plate reader. The measurement reflects the ATP level in the sample and is negatively correlated with the activity of P-gp ATPase. Changes in relative luminescence units $(\triangle R L U)$ were determined by comparing $\mathrm{Na}_{3} \mathrm{VO}_{4}$-treated samples with test compounds and verapamil combination-treated samples.

Calcein-AM retention/efflux assay. Calcein-AM (Invitrogen) was used to determine P-gp-mediated efflux functions in HCT-15 cells in the presence of Genz-123346 and other compounds. Briefly, HCT-15 cells were grown in a low fluorescence, black 96-well plates (Whatman Inc, Piscataway, $\mathrm{NJ})$ to $70-90 \%$ confluence. Cells in $100 \mu 1$ volumes of tissue culture medium were exposed to various concentrations of Genz-123346 or other compounds in $50 \mu \mathrm{l}$ culture medium for $15 \mathrm{~min}$ at $37^{\circ} \mathrm{C}$. Calcein-AM was added to each well in $50 \mu \mathrm{l}$ culture medium giving a final concentration of $0.25 \mu \mathrm{M}$ and the cells were incubated for $15 \mathrm{~min}$ at $37^{\circ} \mathrm{C}$. Then cells were gently agitated. Fluorescence intensity was measured using a BioTek Synergy 2-plate reader with filters appropriate for detection (excitation 485/20, emission 528/20). The fluorescence values were plotted.

Quantitation of cell glucosylceramide levels by mass spectrometry. Glucosylceramide was quantified by mass spectrometry as described (32). Briefly, sphingolipids were analyzed using high-performance liquid chromatography (HPLC) tandem mass spectrometry (32). Cell samples were removed from the $-80^{\circ} \mathrm{C}$ freezer and allowed to thaw. An internal standard cocktail was added to microcentrifuge tubes and dried under nitrogen gas. Cells were added to the tubes and vortexed to help incorporate the internal standards into the cell suspension. Acetonitrile was then used to precipitate proteins from the cell sample, and the resulting suspension was sonicated. The tubes were centrifuged and an aliquot of the supernatant was then transferred to an autosampler for LC/MS/MS analysis. Samples were analyzed on a system consisting of an HTC PAL autosampler, Agilent 1200 HPLC, and API-4000 mass spectrometer. During analysis, samples were stored at $9^{\circ} \mathrm{C}$ in the autosampler cool stack. The HPLC was run in isocratic mode with a normal-phase silica column, and MS/MS was performed in MRM mode.

Flow cytometry analysis of GM1 level on cell surface. GCS inhibition by either Genz-123346 or GCS si/shRNA was determined indirectly by measuring the effect on the cell surface gangliosides GM1 on HCT-15 cells using flow cytometry analysis. GM1 levels on the HCT-15 cells were determined by incubating the cells with Genz-123346 or siRNA transfection for the indicated time after which the cells were harvested and stained using $10 \mu \mathrm{g}$ of recombinant cholera toxin-FITC (Sigma) in $100 \mu 1$ phosphate-buffered saline (PBS) containing $0.5 \%$ bovine serum albumin (BSA) for $30 \mathrm{~min}$ on ice. Cells were washed, resuspended in PBS containing $0.5 \% \mathrm{BSA}$ and the fluorescence was quantified using a FACSCalibur flow cytometer (BD Biosciences, San Jose, CA). CellQuest software (BD Biosciences) was used to analyze the GM1 levels on HCT-15 cell membrane.

\section{Results}

Exposure of drug-resistant cancer cells to Genz-123346 lowers GSL levels and increases sensitivity to cytotoxic drugs. Altered composition of GSL and an increase in GL1 levels are characteristic of multidrug-resistant cancer cells such as KBV-1 and NCI/ADR-RES cells $(5,33,34)$. Quantitative analysis of GCS and GM3S (GM3 synthase) mRNA levels by real-time PCR and measurement of GL1 levels by mass spectrometry confirmed KBV-1 cells exhibit increased expression of GCS and GM3S mRNAs and higher GL1 levels when compared to parental KB3-1. As shown in Fig. 1A, the mRNA level of GCS in the multi-drug-resistant KBV-1 cells was increased 2 -fold and that for GM3 by $>5$-fold. Concomitant with these increases in GCS and GM3S mRNA levels were higher levels of GL2, GM3 and GM1 (measured by mass spectrometry, see Materials and methods) when compared to the parental KB3-1 cells (Table I). Exposure of KBV-1 cells to the GCS 


\section{A. The expression of GCS and GM3S in drug resistant KBV-1 is increased}



B. GCS inhibitor (Genz-123346) sensitizes drug resistant tumor cells but not parental cells to vinblastine

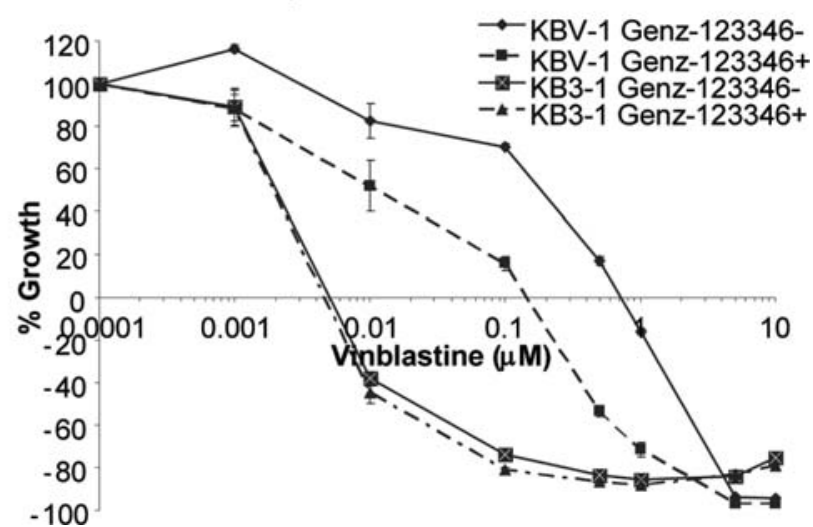

Figure 1. (A) The expression of GCS and GM3S mRNA is increased in drug-resistant KBV-1. The GCS and GM3S mRNA from KBV-1 and KB3-1 cells were analyzed by quantification real-time reverse transcription-PCR. For each gene, mRNA levels were presented relative to the levels of KB3-1 sample (equal to 100). (B) GCS inhibitor (Genz-123346) sensitizes drug-resistant tumor cells but not parental cells to vinblastine. A representative result of GCS inhibitor on cell proliferation. KBV-1 and KB3-1 cells were grown in RPMI medium supplemented with 5\% FBS. Cells (n=2,000) in $100 \mu 1$ growth media were seeded into each well of a 96-well plate. The cells were allowed to attach and grow overnight. The media were then replaced with fresh growth media containing indicated concentrations of vinblastine with (Genz-123346+; $1 \mu \mathrm{M})$ or without (Genz-123346-) GCS inhibitor. The cells were returned to $5 \% \mathrm{CO}_{2}$ humidified atmosphere at $37^{\circ} \mathrm{C}$. Cell proliferation was determined $72 \mathrm{~h}$ after drug addition (Materials and methods). The $\%$ of growth is compared to the cell number at zero concentration of vinblastine.

inhibitor, Genz-123346 (1 $\mu \mathrm{M})$, decreased the levels of all the GSLs downstream of GCS examined indicating effective inhibition of GCS activity. Interestingly, the level of GCS substrate, ceramide (CER), was unchanged.

Having established the conditions for Genz-123346mediated reduction of GSL in KBV-1 cells, the ability of the inhibitor to sensitize the drug-resistant cells to vinblastine was evaluated. Exposure of KBV-1 cells to concentrations of Genz-123346 up to $20 \mu \mathrm{M}$ for $72 \mathrm{~h}$ did not alter cell proliferation (data not shown). KBV-1 cells were more sensitive to vinblastine in the presence of a non-toxic concentration $(1 \mu \mathrm{M})$ of Genz-123346 (Fig. 1B). The $\mathrm{GI}_{50}$ of KBV-1 in the absence of Genz-123346 was $255 \mathrm{nM}$. In the presence of Genz-123346, the $\mathrm{GI}_{50}$ was reduced to $15 \mathrm{nM}$. This enhancement in cytotoxicity was not observed with the parental KB3-1 cells treated in the same manner.

Chemosensitizing effects of varied GCS inhibitors on HCT-15 cells. To test if the observed potentiation of cytotoxicity was restricted to MDR cancer cells generated by selection in cell culture, we examined cell lines with an endogeneous MDR phenotype. HCT15 colon cancer cells, which endogenously express P-gp, were used to test the chemosensitization activity of Genz-123346 as well as other GCS inhibitors (35). Four GCS inhibitors including PDMP, PDMP analogue Genz123346, iminosugar-based C4DGJ and C9DGJ were tested, as shown in Fig. 2A. An increased sensitivity to vinblastine was observed with the ceramide-based inhibitors of GCS (e.g. $1 \mu \mathrm{M}$ PDMP and Genz-123346). In contrast, cells exposed to $1 \mu \mathrm{M}$ of the iminosugar-based GCS inhibitor, C9DGJ and C4DGJ, had only slight changes in sensitivity to vinblastine. HCT15 cells treated with increasing concentrations of Genz123346 showed a concentration-dependent increase in sensi- tivity to $8 \mathrm{nM}$ vinblastine (Fig. 2B). Proliferation of HCT15 cells were effectively inhibited in the presence of $1.25 \mu \mathrm{M}$ Genz-123346 (27.7\% of control) in combination with vinblastine.

To determine whether GCS function was inhibited, lipid compositions at the end of the cell proliferation assays were measured. As illustrated in Fig. 2C, a marked decrease in GSLs was observed in cells treated with Genz-123346, PDMP and C9DGJ for $72 \mathrm{~h}$. C4DGJ treatment also resulted in a reduction of GSLs but to a lesser extent than with the other inhibitors. Consistent with these results, flow cytometry measurements also showed a reduction of cell surface GM1 levels (data not shown).

The ability of Genz-123346 to sensitize HCT-15 to other cytotoxic anti-cancer agents that are P-gp substrates was also determined. Genz-123346 was equally effective at increasing the sensitivity of HCT-15 cells to vincristine, docetaxel and doxorubicin (Fig. 3).

The ceramide-based inhibitors of GCS (PDMP and Genz123346) but not the iminosugar-based inhibitors (C4 and C9 $D G J)$ are substrates of $P-g p$. The observed difference in chemosensitization activity between the ceramide-based inhibitors of GCS (PDMP and Genz-123346) and the iminosugarbased inhibitors (C4 and C9 DGJ) implied that inhibition of GCS activity alone was unlikely to be responsible for the enhanced sensitivity of HCT-15 cells to cytotoxic drugs. We speculated whether discrete interactions between P-gp and the structurally distinct inhibitors of GCS may have a role in driving the observed sensitization effect.

To test this, cell-free P-gp ATPase activity assays were performed (Fig. 4A). The P-gp-Glo assay relies on the ATP dependence of the light-generating reaction of luciferase 


\section{A. Influence of GCS inhibitors on Vinblastine sensitivity in HCT-15 cells}

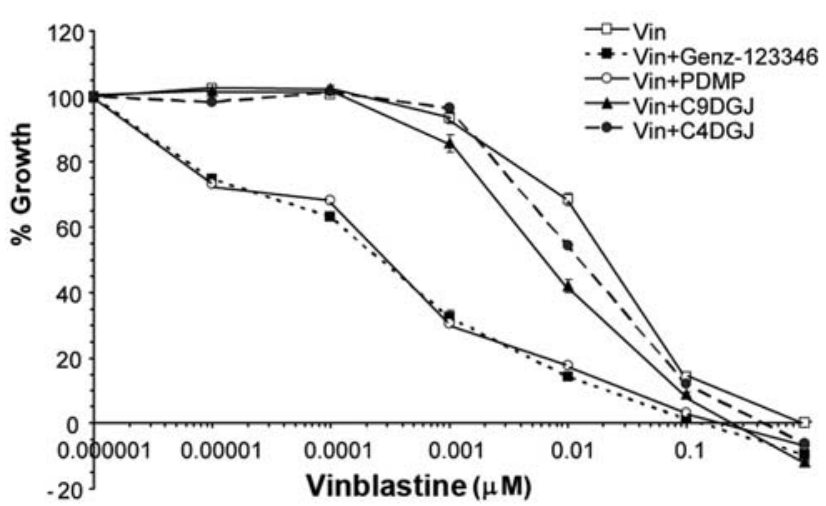

\section{B. Concentration-response curve for Genz-123346 to sensitize HCT-15 cells to vinblastine}

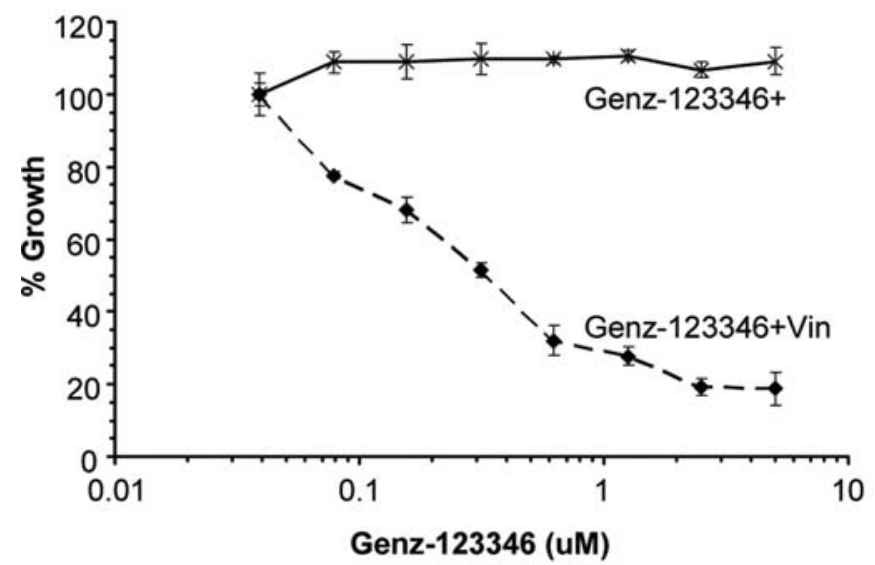

where ATP consumption is detected as a decrease in luminescence; the greater the decrease in signal, the higher the P-gp activity. Sodium orthovanadate was used as a P-gp ATPase inhibitor, and verapamil was used as a positive control. All compounds were tested at 400 and $200 \mu \mathrm{M}$. Genz-123346 (and PDMP to a lesser extent) treatment resulted in a change in luminescence that was similar to or higher than that obtained with the positive control (verapamil), implying that Genz-123346 is a P-gp substrate. Vinblastine, a known P-gp substrate, also showed positivity as a P-gp substrate in this assay.

P-gp efflux activity in the HCT-15 cells, using Calcein-AM, a substrate for both P-gp and MRP1 (ABCC1) transporters, was also determined (36). Increased intracellular calcein fluorescence was observed in the presence of the P-gp inhibitor, verapamil (10-100 $\mu \mathrm{M})$ and vinblastine (10-100 $\mu \mathrm{M})$, a known P-gp substrate (Fig. 4B). An increase in intracellular calcein fluorescence was also detected in the cells exposed to Genz-123346, indicating that Genz-123346 is a P-gp/MRP substrate. In contrast, C4DGJ and 5-FU did not affect

\section{The effects of GCS inhibitors on the sphingolipid composition of HCT-15 cells}

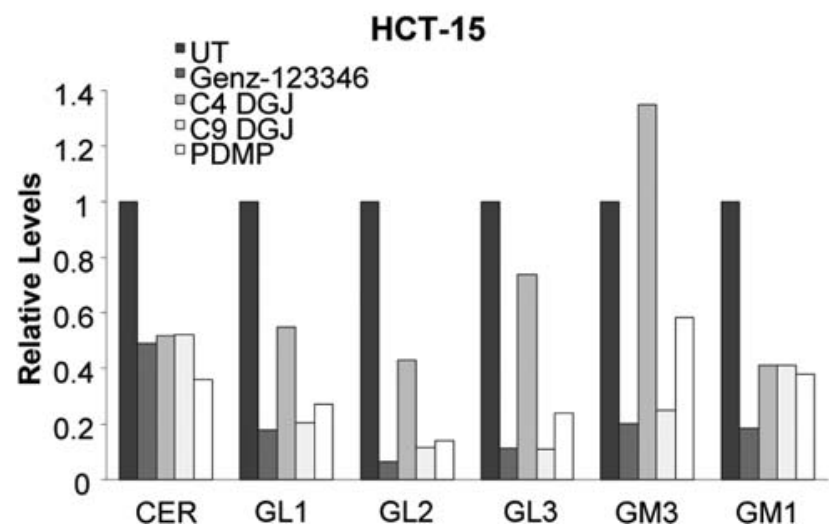

Figure 2. (A) Influence of GCS inhibitors on vinblastine sensitivity of human colon carcinoma HCT-15 cells. A representative result of GCS inhibitor on HCT-15 cell proliferation. HCT-15 cells were grown in RPMI with 5\% FBS. Cells $(\mathrm{n}=2,000)$ in $100 \mu \mathrm{l}$ growth media were seeded into each well of a 96well plate. The cells were allowed to attach and grow overnight. The media were then replaced with fresh growth media containing indicated concentrations of vinblastine (Vin) with $1 \mu \mathrm{M}$ various GCS inhibitors (+Genz-123346; +PDMP; +C4DGJ; +C9DGJ) or without GCS inhibitor. The cells were returned to $5 \% \mathrm{CO}_{2}$ humidified atmosphere at $37^{\circ} \mathrm{C}$. Cell proliferation was determined $72 \mathrm{~h}$ after drug addition (Materials and methods). The $\%$ of growth is compared to the cell number at zero concentration of vinblastine. (B) Concentration-response curve for Genz-123346 to sensitize HCT-15 cells to vinblastine. HCT-15 cells were grown in RPMI medium supplemented with 5\% FBS. Cells $(\mathrm{n}=2,000)$ in $100 \mu 1$ growth media were seeded into each well of a 96-well plate. The cells were allowed to attach overnight. The media were then replaced with fresh growth media containing indicated concentrations of GCS inhibitor Genz-123346 with or without $8 \mathrm{nM}$ vinblastine (Vin). The cells were returned to $5 \% \mathrm{CO}_{2}$ humidified atmosphere at $37^{\circ} \mathrm{C}$. Cell prolife-ration was determined $72 \mathrm{~h}$ after drug addition. The $\%$ of growth is compared to the cell number at zero concentration of vinblastine. (C) The effects of GCS inhibitors on the sphingolipid composition of HCT-15 cells. HCT-15 cells used for the cell proliferation experiment in Fig. 2A were incubated with or without $1 \mu \mathrm{M}$ Genz-123346 or $1 \mu \mathrm{M}$ of other GCS inhibitors for $72 \mathrm{~h}$. After treatments, a variety of GSL levels were measured by mass spectrometry analysis (Materials and methods).

intracellular calcein fluorescence, consistent with previous reports that these compounds are not $\mathrm{P}$-gp substrates $(25,35,37)$.

In a subsequent study, the chemosensitizing effect of Genz-123346 was measured in the presence of the P-gp inhibitor verapamil. As shown in Fig. 4C, inhibition of P-gp by verapamil $(10 \mu \mathrm{M})$ resulted in sensitization of HCT-15 cells to vinblastine. A similar response was observed in Genz-123346 (10 $\mu \mathrm{M})$-treated cells. However, Genz-123346 did not further sensitize the tumor cells to vinblastine in the presence of verapamil, suggesting that the mechanism of action of Genz-123346 was primarily through P-gp, and not GCS inhibition.

Reducing GCS expression did not alter the sensitivity of HCT-15 and HepG2 tumor cells to vinblastine and docetaxol. The results above suggest a less important role of GCS activity in mediating chemosensitization of HCT-15 cells to anti-cancer drugs. To further investigate the role of GCS in chemosensitizing this cell line, siRNA-mediated reduction in 


\section{A. Influence of GCS inhibitors on vincristine sensitivity in HCT-15 cells}

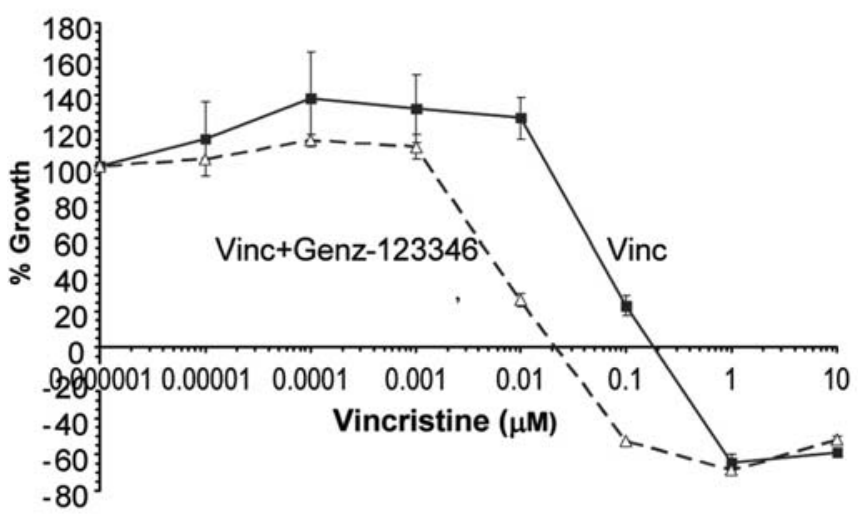

\section{B. Influence of GCS inhibitors on docetaxel sensitivity in HCT-15 cells}

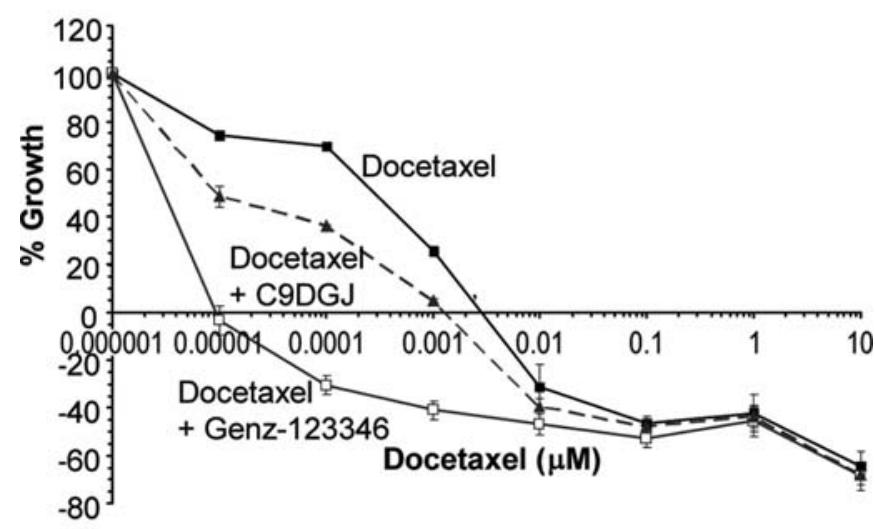

GCS expression was studied. To ensure GCS activity was reduced, two sequential GCS siRNA transfections were performed (Materials and methods) and resultant mRNA levels were quantified as a measure of siRNA efficiency (Fig. 5A). The mRNA level of GCS was significantly reduced $48 \mathrm{~h}$ post siRNA tranfection [22\% of non-targeting (NT) siRNA control] and remained low until four days posttransfection (45\% of NT siRNA control). GM1 ganglioside level, a downstream product of GCS was used to indirectly assess the decrease in GCS expression (28). Results from flow cytometry analysis revealed that the GM1 level on HCT-15 cells decreased as indicated by the shift in fluorescence intensity $48 \mathrm{~h}$ post-the second transfection with siRNA as compared to that of NT siRNA-transfected cells (Fig. 5B). The GM1 level remained low at $72 \mathrm{~h}$ post-second transfection but returned close to the control level of NT siRNA transfected cells at $96 \mathrm{~h}$ post-transfection. Cells were also tested for their

\section{Influence of GCS inhibitors on doxorubicin sensitivity in HCT-15 cells}

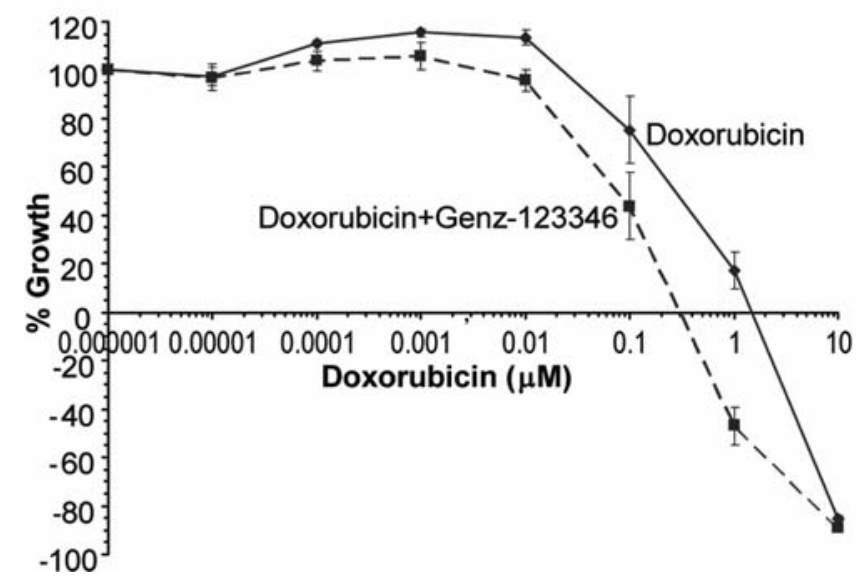

Figure 3. (A) Influence of GCS inhibitors on vincristine sensitivity in HCT-15 cells. HCT-15 cells were grown in RPMI with $5 \%$ FBS. Cells $(n=2,000)$ in $100 \mu 1$ growth media were seeded into each well of a 96-well plate. The cells were allowed to attach and grow overnight. The media were then replaced with fresh growth media containing indicated concentrations of vincristine (Vinc) with or without $1 \mu \mathrm{M}$ Genz-123346 GCS inhibitor. The cells were returned to $5 \% \mathrm{CO}_{2}$ humidified atmosphere at $37^{\circ} \mathrm{C}$. Cell proliferation was determined $72 \mathrm{~h}$ after drug addition (Materials and methods). The $\%$ of growth is compared to the cell number at zero concentration of vincristine. (B) Influence of GCS inhibitors on docetaxel sensitivity in HCT-15 cells. HCT-15 cells were grown in RPMI medium supplemented with $5 \%$ FBS. Cells $(\mathrm{n}=2,000)$ in $100 \mu 1$ growth media were seeded into each well of a 96-well plate. The cells were allowed to attach overnight. The media were then replaced with fresh growth media containing indicated concentrations of docetaxel with or without $1 \mu \mathrm{M}$ Genz-123346 or C9DGJ GCS inhibitors. The cells were returned to $5 \% \mathrm{CO}_{2}$ humidified atmosphere at $37^{\circ} \mathrm{C}$. Cell proliferation was determined $72 \mathrm{~h}$ after drug addition (Materials and methods). The $\%$ of growth is compared to the cell number at zero concentration of docetaxel. (C) Influence of GCS inhibitors on doxorubicin sensitivity in HCT-15 cells. HCT-15 cells were grown in RPMI medium supplemented with $5 \%$ FBS. Cells $(\mathrm{n}=2,000)$ in $100 \mu 1$ growth media were seeded into each well of a 96-well plate. The cells were allowed to attach and grow overnight. The media were then replaced with fresh growth media containing indicated concentrations of doxorubicin with or without $1 \mu \mathrm{M}$ Genz112638C9 GCS inhibitor. The cells were returned to $5 \% \mathrm{CO}_{2}$ humidified atmosphere at $37^{\circ} \mathrm{C}$. Cell proliferation was determined $72 \mathrm{~h}$ after drug addition (Materials and methods). The \% of growth is compared to the cell number at zero concentration of doxorubicin.

response to vinblastine in cell proliferation assays (Fig. 5C). There was no significant difference between GCS siRNAand NT siRNA-transfected cells in response to vinblastine.

To further assess the role of GCS in chemosensitizing tumor cells, a second approach at reducing GCS expression that entails the use of short hairpin RNA (shRNA) against GCS in a different cell line (HepG2) was also assessed. GCS mRNA levels as well as GSL levels were measured posttransfection with shRNAs directed against GCS. Two stable cell lines exhibiting lower levels of GCS mRNA generated using two shRNAs that targeted different GCS sequences (HepG2 GCS-c1 and GCS-c2) were characterized with qRT-PCR. As shown in Fig. 6A, GCS mRNA levels in both cell lines were reduced (33\% of non-silencing control (NS) for GCS-c1 and $29 \%$ of NS control for GCS-c2). Lipid analysis of the two cell lines indicated that GL1, GL2 and GM3 were decreased as well (Fig. 6B). In general, the growth 


\section{A. GCS inhibitors, Genz-123346 and PDMP are substrates for P-gp}
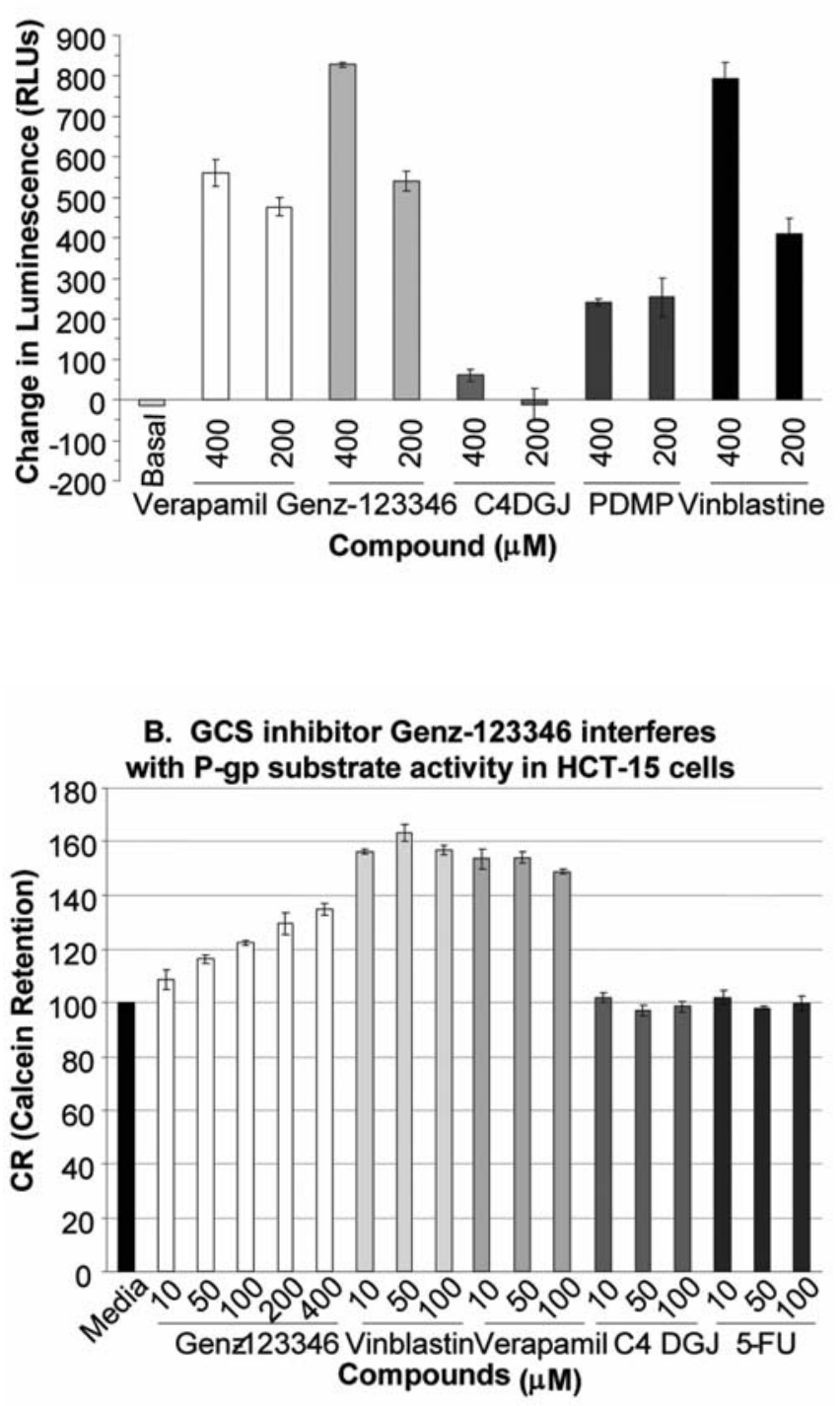

characteristics of the two cell lines expressing lower levels of GCS mRNA, the NS control and parental cells were similar (data not shown). Examination of the response of shRNAknockdowned HepG2 cells and the control cells to vinblastine and docetaxel (Fig. 6C and D) showed they all responded similarly to the drugs, although the GCS-c2 clone showed a moderate increase in sensitivity to docetaxel.

\section{Discussion}

Elevated GL1 has been found in a number of multidrugresistant human cancer cell lines and this feature has been proposed as a marker for MDR in the clinic $(5,6,12)$. GSC is the primary ceramide glycosylase and decreased GCS expression with RNA interference or small molecule inhibitors was thought to result in a buildup of ceramide thereby enhancing the cell chemosensitivity to certain cytotoxic anticancer agents $(8,12,13)$. However, most data generated on GCS-related MDR have been obtained using cells that over-

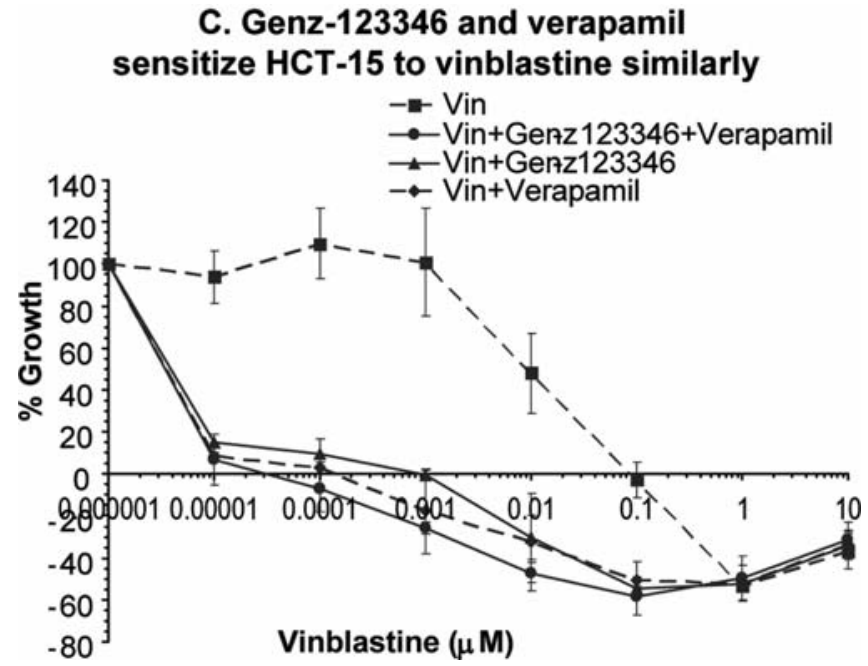

Figure 4. (A) GCS inhibitors, Genz-123346 and PDMP are substrates for P-gp. Untreated, $250 \mu \mathrm{M} \mathrm{Na}_{3} \mathrm{VO}_{4}, 200-400 \mu \mathrm{M}$ verapamil and $200-400 \mu \mathrm{M}$ Genz-123346, PDMP, C4DGJ or vinblastine treated cell-free P-gp ATPase activity assay were performed according to the manufacturer's protocol (Materials and methods). The decrease change in luminescence of untreated samples compared to samples plus $\mathrm{Na}_{3} \mathrm{VO}_{4}$ represents basal P-gp ATPase activity (Basal). The decrease change in luminescence of Verapamil, Genz123346, PDMP, C4DGJ or vinblastine-treated samples represent P-gp ATPase activity. The diagram shows decreased change in luminescence of Genz-123346-treated sample as compared with $\mathrm{Na}_{3} \mathrm{VO}_{4}$ or verapamil, PDMP and other drugs-treated samples. (B) GCS inhibitor Genz-123346 interferes with P-gp substrate activity in HCT-15 cells. Calcein-AM was used to determine P-gp-mediated efflux functions in HCT-15 cells in the presence of Genz-123346 and other compounds. HCT-15 cells were grown to 70-90\% confluence. Cells in $100 \mu 1$ volumes of tissue culture medium were exposed with various concentrations of Genz-123346 or other compounds in $50 \mu 1$ culture medium for $15 \mathrm{~min}$ at $37^{\circ} \mathrm{C}$. Calcein-AM was added to each well in $50 \mu 1$ culture medium with final concentration of $0.25 \mu \mathrm{M}$ ) and the cells were incubated for $15 \mathrm{~min}$ at $37^{\circ} \mathrm{C}$. Fluorescence intensity was measured using a BioTek Synergy 2-plate reader with filters appropriate for detection (excitation 485/20, emission 528/20). The fluorescence values (Calcein retention) were plotted. (C) Genz-123346 and verapamil sensitize HCT-15 to vinblastine similarly. Cell proliferation assays for HCT-15 cells were carried out in the presence of $10 \mu \mathrm{M}$ Genz-123346 with or without $10 \mu \mathrm{M}$ verapamil and the cell proliferation inhibition and for vinblastine was determined as described under Materials and methods. The $\%$ of growth is compared to the cell number at zero concentration of vinblastine.

expressed $\mathrm{ABC}$ transporters, and from cells that had been artificially selected for multi-drug resistance (e.g. NCI/ ADR-RES cells) (4). Thus, the relationship between GSL metabolism via GCS activity and $\mathrm{ABC}$ transporter expression and function needed further elucidation.

P-gp over-expression has long been regarded as the major cause of MDR in a number of human malignancies. In addition, P-gp acts as a drug flippase or phospholipid translocator (38) and P-gp has been shown to transport short-chain fluorescent analogues of sphingomyelin and GL1 across membranes (39). Additionally, it has been proposed that P-gp mediates GL1 translocation across the lipid bilayer, from the cytosolic face of the golgi to the lumen, to provide increased substrate for the luminal synthesis of GL2 and Gb3 (40).

Reduction of P-gp expression was observed in NCI/ADRRES cells transfected with an antisense RNA to GCS or treated with the GCS inhibitor, PPMP (1-phenyl-2-palmitoylamino3-morpholino-1-propanol) (41). The chemosensitizing effect of the GCS inhibitior, PDMP, was observed in MDR cell 
A. Relative GCS expression in HCT-15 cells with GCS siRNA transfection

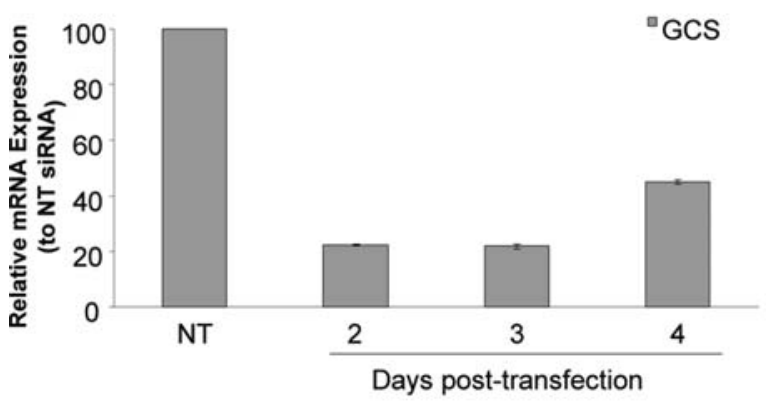

B. GM1 expression in HCT-15 cells with GCS siRNA knockdown

Day 3 post second transfection



C. Influence of GCS siRNA knockdown on vinblastin sensitivity in HCT-15 cells

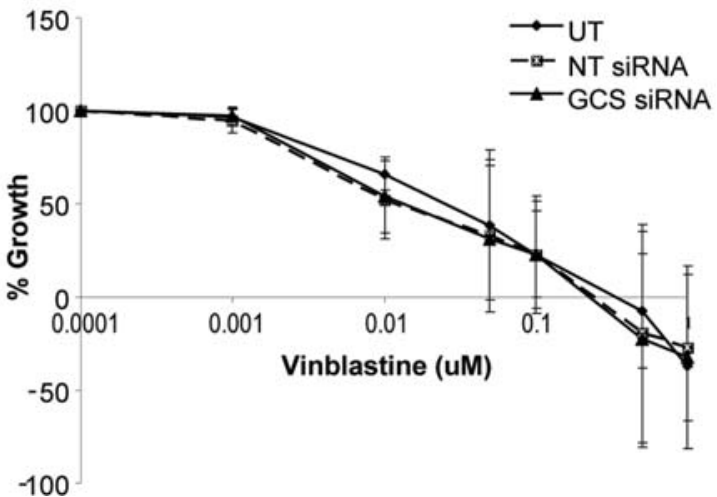

B. GM1 expression in HCT-15 cells with GCS siRNA knockdown

Day 2 post second transfection

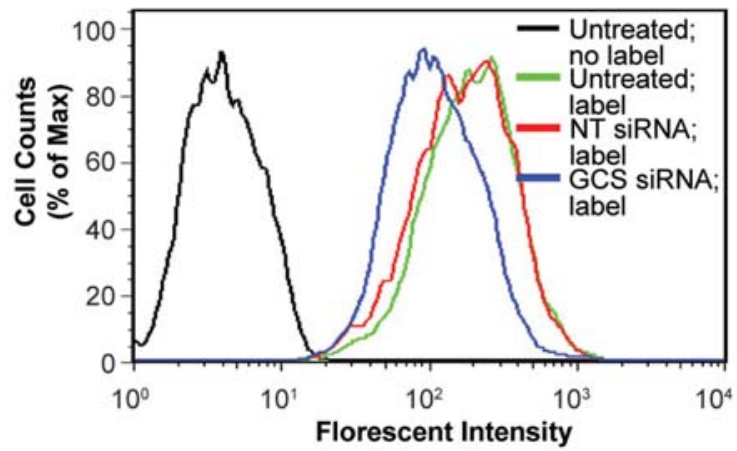

B. GM1 expression in HCT-15 cells with GCS siRNA knockdown

Day 4 post second transfection

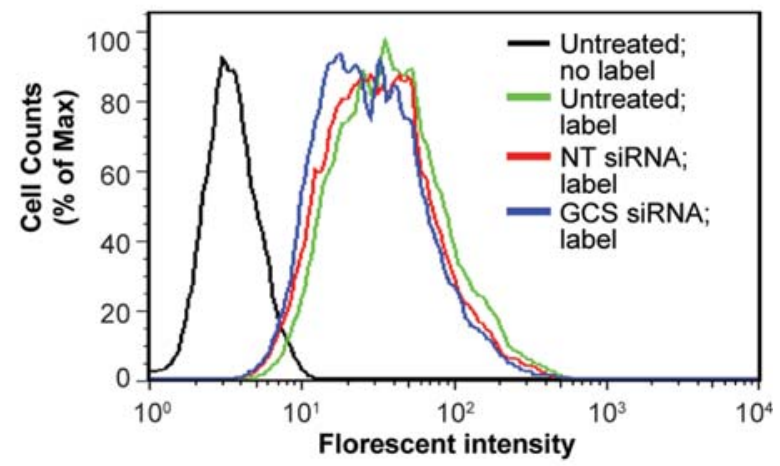

Figure 5. (A) Relative GCS expression in HCT-15 cells with GCS siRNA transfection. The GCS mRNA levels from HCT-15 cells transfected with GCS siRNA for various time were analyzed with quantification real-time reverse transcription-PCR. The mRNA levels were presented relative to the levels of HCT-15 cells transfected with scramble non-targeting siRNA (NT siRNA equal to 100). (B) GM1 expression in HCT-15 cells with GCS siRNA knockdown. Flow cytometry analysis of GM1 level on cell surface was performed to determine indirectly the inhibitory activity of GCS siRNA transfection. HCT-15 cells were cultured under standard conditions and two-time sequential GCS siRNA transfections were performed (Materials and methods). The cells were harvested and stained using recombinant cholera toxin-FITC (Materials and methods). The fluorescence was quantified using a FACSCalibur flow cytometer. (C) Influence of GCS siRNA knockdown on vinblastine sensitivity in HCT-15 cells. The GCS activity was indirectly determined by examining GM1 level on cell surface by flow cytometry (B) for cells used for this assay. The cell proliferation inhibition and for vinblastine was determined as described in Materials and methods. The \% of growth is compared to the cell number at zero concentration of vinblastine.

lines either with P-gp and GCS over-expressing NCI/ADRRES line or with P-gp gene-transfected cell lines but not in P-gp low expressing wild-type cells (22). In a recent review,
Sietsma et al discussed GCS-mediated drug resistance dependent on $\mathrm{ABC}$ transporter proteins and hypothesized that GSL-mediated drug resistance may be dependent on the 


\section{A. Relative expression of GCS in HepG2 cells with GCS shRNA knockdown}

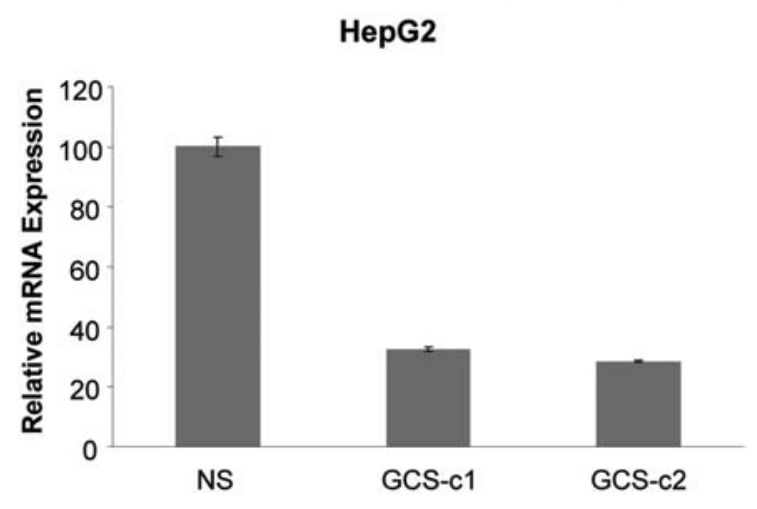

\section{Influence of GCS shRNA knockdown on vinblastine sensitivity in HepG2 cells HepG2}

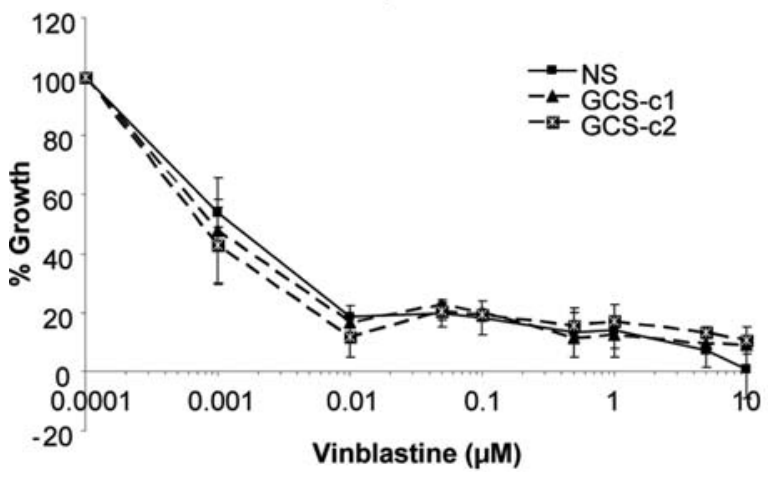

B. The stable knockdown of GCS with shRNA on GSL levels in HepG2 cells

HepG2

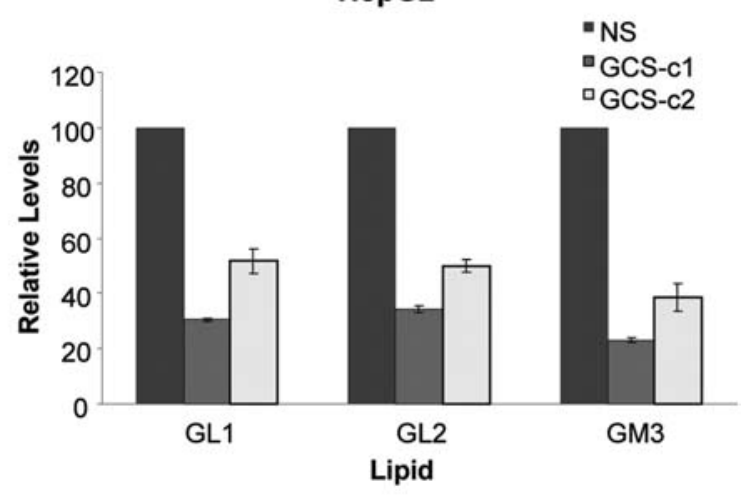

\section{Influence of GCS shRNA knockdown on docetaxel sensitivity in HepG2 cells \\ HepG2}

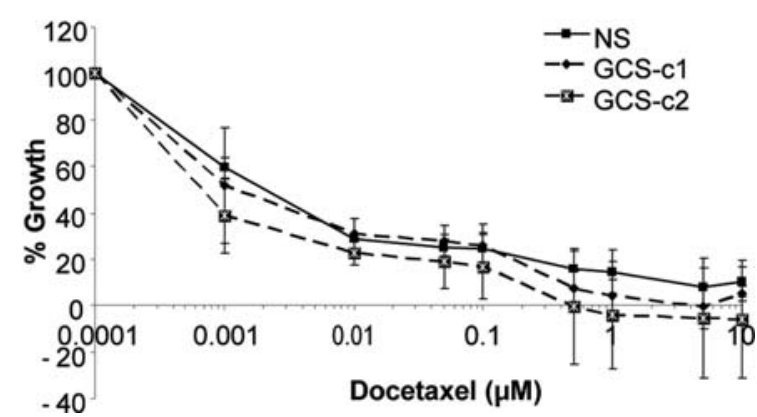

Figure 6. (A) Relative expression of GCS in HepG2 cells with GCS shRNA knockdown. The GCS mRNA levels from HCT-15 cells with GCS shRNA or NT shRNA (NS) were analyzed with quantification real-time reverse transcription-PCR. The mRNA levels were presented relative to the levels of HCT-15 cells with non-targeting shRNA (NS shRNA sample equals to 100). (B) The stable knockdown of GCS with shRNA on GSL levels in HepG2 cells. Analysis of GM1 level on cell by mass spectrometry was performed to determine indirectly the inhibitory activity of GCS in GCS shRNA cells. HCT-15 cells with shRNA knockdown were cultured under standard conditions and analyses were performed as described in Materials and methods. (C) Influence of GCS shRNA knockdown on vinblastine sensitivity in HepG2 cells. The cell proliferation inhibition and for vinblastine was determined as described in Materials and methods. The \% of growth is compared to the cell number at zero concentration of vinblastine. (D) Influence of GCS shRNA knockdown on docetaxel sensitivity in HepG2 cells. The cell proliferation inhibition and for docetaxel was determined as described in Materials and methods. The \% of growth is compared to the cell number at zero concentration of docetaxel.

presence of drug transporter proteins (4). Of note, many previous studies relied on the use of the GCS inhibitor PDMP. Our current study showed that Genz-123346, like PDMP, could sensitize various tumor cells to multiple cancer drugs. We attempted to define whether the chemosensitization effect of PDMP and Genz-123346 could be explained at least partially because PDMP and Genz-123346 are modulaters, or substrates, of P-gp. A study evaluating PDMP chemosensitization of neuroblastoma cells with paclitaxel and vincristine demonstrated that PDMP treatment resulted in a decreased efflux of $\left[{ }^{14} \mathrm{C}\right]$ paclitaxel and $\left[{ }^{3} \mathrm{H}\right]$ vincristine from neuroblastoma cells, similar to treatment with P-gp inhibitors, suggesting an effect of PDMP on the transporter proteins P-gp and/or multidrug resistance protein (15). Consistent with this result, we found that PDMP and its analogue Genz-123346 are potential substrates of $\mathrm{P}$-gp using the cell-free $\mathrm{P}$-gp ATPase activity assays (Fig. 4A). We did not observe Genz123346 chemosensitization effect to non P-gp substrate anticancer agent, such as 5-FU (data not shown). In addition, $\mathrm{ABC}$ transporter efflux assays employing a fluorescent P-gp or MRP substrate calcein-AM in HCT-15 cells revealed that the functional activity of these transporters was affected in the presence of Genz-123346 (Fig. 4B). Genz-123346 did not further sensitize HCT-15 cells to vinblastine in the presence of a P-gp inhibitor (Fig. 4C). Nevertheless, cellular drug accumulation in P-gp over-expressing NCI/ADR-RES cells treated with PDMP was not observed in previous studies $(22,37)$. Therefore, the modulation of P-gp function by PDMP seems, at the very least, to be cell line-dependent.

In this study, we further explored the biological role of GCS in chemosensitization of tumor cells using RNA interference. Consistent with prior genetic studies in GM95, CHP-100 human neuroepithelioma and drug-selected multidrug-resistant cells $(25,42,43)$, we found siRNA and shRNA knockdown of GCS in HCT-15 and HepG2 cancer cells, respectively, did not alter their response to anti-cancer cytotoxic drugs. Veldman et al studied GM95 mouse melanoma cells which lack functional GCS and do not express detectable P-gp or MRP1. Compared to non-mutant cells, the mutant cells showed no difference in viability upon exposure to various 
drugs (42). Furthermore, potent and non-toxic iminosugar based GCS inhibitors had no chemosensitizing effect on wild-type GM95 and multidrug-resistant tumor cells $(25,42)$. Altogether, the evidence from both genetic and pharmacological studies suggested that alterations of the cellular ceramide metabolism through GCS inhibition may have limited importance in chemosensitization.

Not withstanding these observations, we cannot exclude the possibility that GCS inhibition may have contributed to the chemosensitization effect within alternative cellular context. When iminosugar-based GCS inhibitors were applied to chronic lymphocytic leukaemia (CLL) cells to reduce GSL levels, Gerrard et al observed that the GCS inhibitors sensitized CLL cells to the conventional cytotoxic drug 2-chlorodeoxyadenosine (CdA) and the cytostatic drugs chlorambucil and fludarabine. In addition, they did not appear to have any effect on P-gp functional activity (44). Recent study demonstrated that with NCI/ADR-RES cells were sensitized to cytotoxic drugs when cancer cells were treated with a mixedbackbone anti-sense oligos against GCS (MBO-asGCS) both in vitro and in vivo (45). We also observed that in HCT-15 cells, C9DGJ demonstrated a chemosensitization effect with docetaxel, although it was not as robust as Genz-123346 (Fig. 3B). Nevertheless, the selectivity of GCS inhibition of iminosugar based GCS inhibitors is subjective to D-gluco-, D-galacto and L-ido-stereochemistry in combination with a hydrophobic substituent on the endocyclic nitrogen inhibited GCS (29). Again, the sensitization effect of GCS inhibitors should be interpreted with caution.

Our study provides clarity for the basis for by which PDMP-based GCS inhibitors mediate sensitization of tumor cells to anti-cancer cytotoxic drugs. The data from our current study suggest that the chemosensitizing effect of PDMP-based GCS inhibitor Genz-123346 is primarily mediated through P-gp modulation. If GCS inhibition is important for multidrug-resistance, at the very least it is likely to be cell line-dependent. These observations suggest that chemosensitization data obtained using these inhibitors should be interpreted with caution.

\section{Acknowledgments}

We thank Drs Kim Alving, Yunxiang Zhu, Paul Mason, Steven Schmid, Cynthia Arbeeny, John Connelly, Johanne M. Kaplan and Richard J. Gregory for their scientific contributions to the project. We gratefully acknowledge technical support from Leslie Kurtzberg, Stephanie Roth and Roy Krumbholz. Financial support for this study was from Genzyme Corp.

\section{References}

1. Szakacs G, Paterson JK, Ludwig JA, Booth-Genthe C and Gottesman MM: Targeting multidrug resistance in cancer. Nat Rev Drug Discov 5: 219-234, 2006.

2. Leonard GD, Fojo T and Bates SE: The role of ABC transporters in clinical practice. Oncologist 8: 411-424, 2003.

3. Lavie Y and Liscovitch M: Changes in lipid and protein constituents of rafts and caveolae in multidrug resistant cancer cells and their functional consequences. Glycoconj J 17: 253-259, 2000.

4. Sietsma H, Veldman RJ and Kok JW: The involvement of sphingolipids in multidrug resistance. J Membr Biol 181: 153-162, 2001.
5. Lavie $\mathrm{Y}$, Cao H, Bursten SL, Giuliano AE and Cabot MC: Accumulation of glucosylceramides in multidrug-resistant cancer cells. J Biol Chem 271: 19530-19536, 1996.

6. Lucci A, Cho WI, Han TY, Giuliano AE, Morton DL and Cabot MC: Glucosylceramide: a marker for multiple-drug resistant cancers. Anticancer Res 18: 475-480, 1998.

7. Wennekes T, van den Berg RJ, Boot RG, van der Marel GA, Overkleeft HS and Aerts JM: Glycosphingolipids-nature, function, and pharmacological modulation. Angew Chem Int Ed Engl 48: 8848-8869, 2009.

8. Modrak DE, Gold DV and Goldenberg DM: Sphingolipid targets in cancer therapy. Mol Cancer Ther 5: 200-208, 2006.

9. Bleicher RJ and Cabot MC: Glucosylceramide synthase and apoptosis. Biochim Biophys Acta 1585: 172-178, 2002.

10. Liu YY, Han TY, Giuliano AE and Cabot MC: Expression of glucosylceramide synthase, converting ceramide to glucosylceramide, confers adriamycin resistance in human breast cancer cells. J Biol Chem 274: 1140-1146, 1999.

11. Liu YY, Han TY, Giuliano AE, Ichikawa S, Hirabayashi Y and Cabot MC: Glycosylation of ceramide potentiates cellular resistance to tumor necrosis factor-alpha-induced apoptosis. Exp Cell Res 252: 464-470, 1999.

12. Liu YY, Han TY, Giuliano AE and Cabot MC: Ceramide glycosylation potentiates cellular multidrug resistance. FASEB J 15: 719-730, 2001.

13. Liu YY, Han TY, Giuliano AE, Hansen N and Cabot MC: Uncoupling ceramide glycosylation by transfection of glucosylceramide synthase antisense reverses adriamycin resistance. J Biol Chem 275: 7138-7143, 2000.

14. Regina Todeschini A and Hakomori SI: Functional role of glycosphingolipids and gangliosides in control of cell adhesion, motility, and growth, through glycosynaptic microdomains. Biochim Biophys Acta 1780: 421-433, 2008.

15. Sietsma H, Veldman RJ, Kolk D, et al: 1-phenyl-2-decanoylamino3-morpholino-1-propanol chemosensitizes neuroblastoma cells for taxol and vincristine. Clin Cancer Res 6: 942-948, 2000.

16. Barbour S, Edidin M, Felding-Habermann B, Taylor-Norton J, Radin NS and Fenderson BA: Glycolipid depletion using a ceramide analogue (PDMP) alters growth, adhesion, and membrane lipid organization in human A431 cells. J Cell Physiol 150: 610-619, 1992.

17. Olshefski RS and Ladisch S: Glucosylceramide synthase inhibition enhances vincristine-induced cytotoxicity. Int J Cancer 93: 131-138, 2001.

18. Liour SS and Yu RK: Differential effects of three inhibitors of glycosphingolipid biosynthesis on neuronal differentiation of embryonal carcinoma stem cells. Neurochem Res 27: 1507-1512, 2002 .

19. Lee L, Abe A and Shayman JA: Improved inhibitors of glucosylceramide synthase. J Biol Chem 274: 14662-14669, 1999.

20. Kok JW, Babia T, Filipeanu CM, Nelemans A, Egea G and Hoekstra D: PDMP blocks brefeldin A-induced retrograde membrane transport from golgi to ER: evidence for involvement of calcium homeostasis and dissociation from sphingolipid metabolism. J Cell Biol 142: 25-38, 1998.

21. Griner RD and Bollag WB: Inhibition of [(3)H]thymidine transport is a nonspecific effect of PDMP in primary cultures of mouse epidermal keratinocytes. J Pharmacol Exp Ther 294: 1219-1224, 2000

22. Shabbits JA and Mayer LD: P-glycoprotein modulates ceramide-mediated sensitivity of human breast cancer cells to tubulin-binding anticancer drugs. Mol Cancer Ther 1: 205-213, 2002.

23. Lavie Y, Cao H, Volner A, et al: Agents that reverse multidrug resistance, tamoxifen, verapamil, and cyclosporin A, block glycosphingolipid metabolism by inhibiting ceramide glycosylation in human cancer cells. J Biol Chem 272: 1682-1687, 1997.

24. Xie P, Shen YF, Shi YP, et al: Overexpression of glucosylceramide synthase in associated with multidrug resistance of leukemia cells. Leuk Res 32: 475-480, 2008.

25. Norris-Cervetto E, Callaghan R, Platt FM, Dwek RA and Butters TD: Inhibition of glucosylceramide synthase does not reverse drug resistance in cancer cells. J Biol Chem 279: 40412-40418, 2004.

26. Sietsma H, Dijkhuis AJ, Kamps W and Kok JW: Sphingolipids in neuroblastoma: their role in drug resistance mechanisms. Neurochem Res 27: 665-674, 2002.

27. Dijkhuis AJ, Klappe K, Jacobs S, et al: PDMP sensitizes neuroblastoma to paclitaxel by inducing aberrant cell cycle progression leading to hyperploidy. Mol Cancer Ther 5: 593-601, 2006. 
28. McEachern KA, Fung J, Komarnitsky S, et al: A specific and potent inhibitor of glucosylceramide synthase for substrate inhibition therapy of Gaucher disease. Mol Genet Metab 91: 259-267, 2007.

29. Wennekes T, Meijer AJ, Groen AK, et al: Dual-action lipophilic iminosugar improves glycemic control in obese rodents by reduction of visceral glycosphingolipids and buffering of carbohydrate assimilation. J Med Chem 53: 689-698, 2010.

30. Shen DW, Cardarelli C, Hwang J, et al: Multiple drug-resistant human KB carcinoma cells independently selected for highlevel resistance to colchicine, adriamycin, or vinblastine show changes in expression of specific proteins. J Biol Chem 261: 7762-7770, 1986.

31. Boyd MR and Pall KD: Some practical considerations and applications of the National Cancer Institute In Vitro Anticancer Drug Discovery Screen. Drug Dev Res 34: 91-109, 1995.

32. Silberstein C, Copeland DP, Chiang W, Repetto HA and Ibarra C: A glucosylceramide synthase inhibitor prevents the cytotoxic effects of shiga toxin-2 on human renal tubular epithelial cells. J Epithelial Biol Pharmacol 1: 71-75, 2008

33. Liu YY, Yu JY, Yin D, et al: A role for ceramide in driving cancer cell resistance to doxorubicin. FASEB J 22: 2541-2551, 2008.

34. Prinetti A, Millimaggi D, D'Ascenzo S, et al: Lack of ceramide generation and altered sphingolipid composition are associated with drug resistance in human ovarian carcinoma cells. Biochem J 395: 311-318, 2006.

35. Szakacs G, Annereau JP, Lababidi S, et al: Predicting drug sensitivity and resistance: profiling $\mathrm{ABC}$ transporter genes in cancer cells. Cancer Cell 6: 129-137, 2004.

36. Glavinas H, Krajcsi P, Cserepes J and Sarkadi B: The role of $\mathrm{ABC}$ transporters in drug resistance, metabolism and toxicity. Curr Drug Deliv 1: 27-42, 2004.

37. Norris-Cervetto E, Butters TD, Martin C, Modok S, Dwek RA and Callaghan R: Can P-glycoprotein influence the bioavailability of iminosugar-based glucosylceramide synthase inhibitors? Eur J Pharmacol 530: 195-204, 2006.
38. van Helvoort A, Smith AJ, Sprong H, et al: MDR1 P-glycoprotein is a lipid translocase of broad specificity, while MDR3 P-glycoprotein specifically translocates phosphatidylcholine. Cell 87 : 507-517, 1996

39. van Helvoort A, Giudici ML, Thielemans M and van Meer G: Transport of sphingomyelin to the cell surface is inhibited by brefeldin A and in mitosis, where C6-NBD-sphingomyelin is translocated across the plasma membrane by a multidrug transporter activity. J Cell Sci 110: 75-83, 1997.

40. Lala P, Ito S and Lingwood CA: Retroviral transfection of Madin-Darby canine kidney cells with human MDR1 results in a major increase in globotriaosylceramide and 10(5)- to 10(6)-fold increased cell sensitivity to verocytotoxin. Role of p-glycoprotein in glycolipid synthesis. J Biol Chem 275: 6246-6251, 2000.

41. Gouaze V, Liu YY, Prickett CS, Yu JY, Giuliano AE and Cabot MC: Glucosylceramide synthase blockade down-regulates P-glycoprotein and resensitizes multidrug-resistant breast cancer cells to anticancer drugs. Cancer Res 65: 3861-3867, 2005.

42. Veldman RJ, Mita A, Cuvillier O, et al: The absence of functional glucosylceramide synthase does not sensitize melanoma cells for anticancer drugs. FASEB J 17: 1144-1146, 2003.

43. Di Sano F, Di Bartolomeo S, Fazi B, et al: Antisense to glucosylceramide synthase in human neuroepithelioma affects cell growth but not apoptosis. Cell Death Differ 9: 693-695, 2002.

44. Gerrard G, Butters TD, Ganeshaguru K and Mehta AB: Glucosylceramide synthase inhibitors sensitise CLL cells to cytotoxic agents without reversing P-gp functional activity. Eur J Pharmacol 609: 34-39, 2009.

45. Patwardhan GA, Zhang QJ, Yin D, et al: A new mixedbackbone oligonucleotide against glucosylceramide synthase sensitizes multidrug-resistant tumors to apoptosis. PLoS One 4: e6938, 2009. 